2012 VOLUME 15 No 5 


\section{SOME COMMENTS ON THE SCHEME OF ARRANGEMENT AS AN "AFFECTED TRANSACTION" AS DEFINED IN THE COMPANIES ACT 71 OF 2008}

SM Luiz*

\section{$1 \quad$ Introduction}

A change in or the consolidation of control of a company can be achieved in many different ways and one way is to use a scheme of arrangement. Schemes of arrangement began to be used to effect takeovers after the English Courts sanctioned a scheme in the case of In re National Bank Ltd ${ }^{1}$ which resulted in one person acquiring control of all the issued shares of a company. ${ }^{2}$

Prior to the coming into force of the Companies Act 71 of 2008 (hereafter the Companies Act 2008), schemes of arrangement were regulated by sections 311-313 of the Companies Act 61 of 1973 (herafter the Companies Act 1973). If the scheme resulted in an "affected transaction"3 and involved a company to which the Securities Regulation Code in Takeovers and Mergers (hereafter the "Code") applied, ${ }^{4}$ it was also regulated by the general principles and rules of that Code ${ }^{5}$ Rule 29 of the Code was the only rule that specifically referred to schemes of arrangement. It clarified that where an offer in respect of an affected transaction was implemented by way of such a scheme, the company proposing the scheme was deemed to be the offeree company, and the person who became the holder of relevant equity securities of the company after the scheme was sanctioned by the courts was deemed to be the offeror. $^{6}$

Stephanie M Luiz. BA, LLB (UKZN), LLM (Cantab), HDip Co Law (Wits), LLD (Unisa). Professor, School of Law, University of KwaZulu-Natal. Email: luiz@ukzn.ac.za.

1 In re National Bank Ltd [1966]1 All ER 1006 (ChD).

2 See Luiz Securities Regulation Code 577-578.

3 As defined in s 440A(1) Companies Act 61 of 1973.

4 See s A(3) of the Securities Regulation Code in Takeovers and Mergers for a statement of the companies to which the Code applied.

5 See Luiz 1997 SA Merc LJ 239-264.

6 The word "offer" was defined as including an offer in respect of an affected transaction, however affected: s B(3) Additional Definitions of the Code. 
Speaking generally, the definition of an affected transaction in the Companies Act 1973 covered transactions which resulted in the vesting of the control of a company in a person (or concert parties) who previously did not have control ${ }^{7}$ and transactions which resulted in a person (or concert parties) acquiring or becoming the sole holder of all the securities of a company or of a particular class. ${ }^{8}$ Transactions involving an acquisition by a person (or concert parties) of further voting securities in excess of the limits prescribed in rule 8 of the Code were also covered. ${ }^{9}$ The last type of transaction covered by the definition was a disposal of the whole or substantially the whole of the undertaking or the assets of the company as contemplated in section 228 of the Companies Act $1973 .^{10}$

Except for the section 228 disposal, the focus of the definition of an "affected transaction" in the Companies Act 1973 was on a change of control or consolidation of control of the offeree company (the target company) and the definition of control focused on the holding of securities allowing a person to exercise or cause the exercise of at least 35 per cent of the voting rights. Thus although a scheme of arrangement was not specifically defined as an affected transaction under the Companies Act 1973, it would have been covered by the definition if it resulted in any of the types of transaction covered by the definition. ${ }^{11}$ The focus was on the result of the transaction, rather than on its structure.

7 "Control" was defined as the holding of shares or other securities which entitled the holder to exercise (or cause the exercise of) 35 per cent or more of the voting rights at meetings of the company (irrespective of whether or not the person had de facto control): $s 440 \mathrm{~A}(1)$ Companies Act 61 of 1973 rw s B(5) of the Code.

8 Section 440A(1)(a) Companies Act 61 of 1973.

9 See s $440 A(1)(b)$ Companies Act 61 of 1973. These types of transactions were effectively a consolidation of control, which would trigger the mandatory offer provisions.

10 Section 440A(1)(c) rw s 228 Companies Act 61 of 1973. For a more detailed consideration of the definition of an affected transaction in the Companies Act 1973, see Luiz 2004 SA Merc LJ 1-16.

11 For example, a scheme of arrangement would have been covered by the definition of "affected transaction" if the scheme had the effect of either vesting control of any company in a person (or concert parties) who did not previously have control or had the effect of any person (or concert parties) becoming sole holder of all securities of a company or of a particular class or if it involved the acquisition of securities in excess of the prescribed limits (see $s$ 440A(1)(a)-(b) Companies Act 61 of 1973). If the scheme involved a company to which the Code applied, it would then have been regulated by the Code. 
The Companies Act 2008 has adopted a different approach to affected transactions. The definition of "affected transaction"12 focuses (at least initially) on specific types of transactions. For example, a disposal of all or the greater part of the assets or undertaking of a regulated company as contemplated in section 112 is defined as an affected transaction, as well as an amalgamation or merger as contemplated in section 113, provided it involves at least one regulated company. ${ }^{13}$ A scheme of arrangement between a regulated company and its shareholders as contemplated in section 114 is also now specifically included under the definition of an "affected transaction". ${ }^{14}$ The definition does not immediately focus on transactions resulting in changes or consolidation of control of the offeree company (the target company). ${ }^{15}$

The fact that specific named types of transactions are defined as affected transactions (for example, a scheme of arrangement involving a regulated company) indicates that the definition of an "affected transaction" in the Companies Act 2008 covers not only situations where there is a change or consolidation of control in the context of the voting securities of a company. It is no longer accurate to assert as Marais JA did in Sefalana Employee Benefits Organisation $v$ Haslam $^{16}$ when commenting on the definition of an "affected transaction" in the Companies Act 1973 that the definition makes "a change of control a sine qua non of an affected

12 See s 117(1)(c) Companies Act 71 of 2008. Affected transactions are regulated by Parts B and C Chapter 5 Companies Act 71 of 2008 as well as by the Takeover Regulations. The Takeover Regulations (which replace the Code) are prescribed by the Minister in consultation with the Takeover Regulation Panel (hereafter the "TRP", established by s 196 Companies Act 71 of 2008 as successor to the Securities Regulation Panel) in terms of s 120 Companies Act 71 of 2008. See Chapter 5 (regs 81-122) of the Companies Regulations 2011 published: GG 34239 of 26 April 2011.

13 Section 117(1)(c)(i)-(ii) Companies Act 71 of 2008. "Regulated companies" are companies to which Parts B and C of the Companies Act 2008 as well as the Takeover Regulations apply and are public companies, state-owned companies (unless exempted under $s 9$ ) and certain private companies: s 117(1)(i) rw s 118(1)-(2). A private company will be a regulated company only if its Memorandum of Incorporation expressly provides that the company and its securities are subject to Parts $\mathrm{B}$ and $\mathrm{C}$ and the Takeover Regulations or if more than 10 per cent of the issued securities of that company "have been transferred, other than by transfer between or among related or inter-related persons, within the period of 24 months immediately before the date of a particular affected transaction or offer": s 118(1)-(2) rw reg 91. Note that reg 91(2)(b) stipulates that a buy back by a company of securities that are cancelled is not a transfer for the purposes of assessing if the percentage threshold has been achieved. The definition of related or interrelated persons is found in $\mathrm{s} 1 \mathrm{rw} \mathrm{s} 2(1)(\mathrm{a})$-(c).

14 See s 117(c)(iii) rw s 114 subject to s 118(3) Companies Act 71 of 2008.

15 For other types of transactions included under the definition of "affected transaction" which may or may not involve a change or consolidation of control, see s 117(1)(c))(iv)-(vii) Companies Act 71 of 2008.

16 Sefalana Employee Benefits Organisation v Haslam 20002 SA 415 (SCA) 422. 
transaction". The regulation of transactions which are affected transactions (as defined) would now seem to be more about the regulation of situations involving what could be viewed as an alteration of the fundamental nature of a regulated company rather than exclusively about the regulation of transactions which would result in a change or consolidation of control of the voting securities of the company. Although a scheme of arrangement involving a regulated company may well result in a change of control or a consolidation of the control of the company in relation to the voting securities of that company, there is no specific requirement that this be the result before it falls under the definition of an affected transaction. The focus is on the scheme itself and not on the effect of the scheme. ${ }^{17}$

Schemes of arrangement involving regulated companies and their shareholders are a common occurance and a commercial reality. It is thus important to know what actually constitutes such a scheme. The importance becomes obvious if it is noted that section 121 of the Companies Act 2008 requires that any person making an offer which, if accepted, would result in an affected transaction is obliged to comply with all of the reporting or approval requirements of Part $C$ of Chapter 5 of the Act and the Takeover Regulations, except to the extent that the Takeover Regulation Panel (hereafter the TRP) has granted an exemption. Further, all persons are prohibited from giving effect to an affected transaction unless the TRP has either issued a compliance certificate or has granted an exemption in respect of the specific transaction. ${ }^{18}$

The purpose of this article is therefore to comment generally on the definition of a scheme of arrangement as an affected transaction, highlighting the elements of a

17 As a scheme of arrangement between a regulated company and its shareholders as contemplated in s 114 is now specifically defined as an "affected transaction" (see s 117(1)(c)(iii) Companies Act 71 of 2008) it is regulated by Parts B and C Chapter 5 of the Companies Act 71 of 2008 and by the Takeover Regulations. A scheme of arrangement involving a regulated company but which is pursuant to an approved business rescue plan under Chapter 6 Companies Act 71 of 2008 is not regulated by Part B and C Chapter 5 of the Companies Act 71 of 2008 and the Takeover Regulations (see s 118(3)) but would be governed by the provisions of Chapter 6. Further, if a scheme of arrangement does not involve a regulated company it would also not be governed by those provisions. However, the provisions regulating fundamental transactions would apply (see ss 114-115). Note that there is no specific definition of a "fundamental transaction", although Part A Chapter 5 or the Companies Act 71 of 2008 is headed "Approval for certain fundamental transactions".

18 Section 121(b) Companies Act 71 of 2008. 
scheme of arrangement. In this context specific consideration will be given to transactions which include a re-acquisition by the company of its own previously issued securities and when such a re-acquisition would on its own be considered to be a scheme of arrangement and an affected transaction. Comment will be included on the obligation to appoint an independent expert to report on the scheme and the relevance, if any, of the solvency and liquidity of the company embarking on a scheme of arrangement. Finally, consideration will be given to the need to have a scheme of arrangement approved by a special resolution and the potential exclusion of certain voting rights.

\section{Elements of a scheme of arrangement}

The definition of an "affected transaction" includes a scheme of arrangement between a regulated company and its shareholders "as contemplated in section 114". ${ }^{19}$ Section 114(1) provides that the board of a company may propose and implement a scheme of arrangement between the company and the holders of any class of securities, provided the required approvals have been obtained. ${ }^{20}$ It is also specifically stated that the scheme could include among other things one or more of the following elements or methods: a consolidation of different classes of securities, a division of securities into different classes, an expropriation of securities, an exchange of securities, or a re-acquisition by the company of its own securities. ${ }^{21}$

The purpose of listing the possible elements that may be included as part of a scheme of arrangement is to put to rest most of the debates that have occurred in the context of the interpretation of section 311 (the scheme of arrangement provision) under the Companies Act 1973. Those centered on issues such as whether shareholders could have their shares expropriated in exchange for cash or whether an arrangement meant that the shareholders' interests could be altered but not altogether extinguished. ${ }^{22}$ Another issue that was debated was the extent to

19 See s 117(i)(c)(iii) Companies Act 71 of 2008.

20 See s 115 Companies Act 71 of 2008 for the required approvals.

21 See s 114(1)(a)-(f) Companies Act 71 of 2008.

22 For a reference to these issues and the relevant cases, see Luiz 1997 SA Merc LJ 248-249. 
which the company had to play an active role in the scheme before it could be called an arrangement as between the company and a class of its shareholders. ${ }^{23}$

Despite listing some methods that may be included in a scheme of arrangement, section 114 of the Companies Act 2008 does not include a definition of a scheme of arrangement. (Contrast this for example with the inclusion under the definition of an "affected transaction" of an amalgamation or merger as contemplated in section 113, which is specifically defined in section 1.) The only element that would seem to be required to make a scheme a scheme of arrangement as contemplated under section 114 is that it must be an arrangement between the company and holders of any class of securities in that company. The extent to which the company would need to be actively involved in the scheme to make it such an arrangement is debatable, but all of the methods listed would clearly involve the company in at least a number of administrative tasks.

Schemes of arrangement may be structured in many different ways and could include, for example, a consolidation of different classes of securities or a reacquisition by the company of its own securities. ${ }^{24}$ However, the question arises whether, for example, any proposal by a company to re-acquire some of its shares in terms of section 48 would constitute a scheme of arrangement as contemplated in section 114. The answer is important, as it would determine the sections and rules that regulate the proposed transaction and the procedure that must be followed and the approvals that must be obtained.

If the proposed arrangement "contemplated in this section" (ie section 114) may have as a result the re-acquisition by the company of any (emphasis added) of its previously issued securities, section 48 (which regulates the re-acquisition by a company of its own shares) will apply to the proposed arrangement. ${ }^{25}$ However, this

23 See for example Ex parte Satbel (Edms) Bpk: In re Meyer v Satbel (Edms) Bpk 19844 SA 347 (W) 359-360; Ex parte Satbel (Pty) Ltd (Meyer intervening) 19873 SA 405 (C) 443 and 444; Ex parte NBSA Centre Ltd 19872 SA 783 (T) 809; Namex v Kommissaris van Binnelandse Inkomste 19942 SA 265 (A) 294.

24 See s 114(1) Companies Act 71 of 2008.

25 Section 114(4) Companies Act 71 of 2008. Although both s 114(4) and s 114(1)(e) refer to the reacquisition of issued securities of the company, s 48 specifically regulates the re-acquisition by a 
does not tell us when an arrangement is of the kind contemplated in section 114 . Would any re-acquisition by a company of its own securities constitute such an arrangement? If not, only section 48 would be applicable to the transaction.

It is clear that a re-acquisition in terms of section 48 which involves the company in an acquisition of more than 5 per cent (emphasis added) of the issued shares of any particular class of the company's shares triggers the application of sections 114 and 115 (provisions which apply to schemes of arrangements) ${ }^{26}$ However, this does not tell us if this re-acquisition now becomes an arrangement as contemplated in section 114.

It might be asserted that it is neither here nor there whether one calls a re-acquisition of more than 5 per cent by the company a scheme of arrangement as contemplated in section 114 or not. The fact is that if such a re-acquisition is proposed by the board, section 48(8)(b) requires compliance with sections 114 and 115 . However, it might well be important to answer the question, particularly if it involves a regulated company. This is because "a scheme of arrangement between a regulated company and its shareholders, as contemplated in section 114", falls within the definition of an affected transaction ${ }^{27}$ and the implications of that are quite vast. The provisions of section 121 have already been mentioned above. ${ }^{28}$ Thus not only would there need to be compliance with the provisions of sections 114 and 115 specifically referred to in section 48(8)(b), but there would also need to be compliance with the Takeover Regulations culminating in the receipt of a compliance certificate, or the company would need to apply for exemption for the transaction. The effect of interpreting a reacquisition by a company of more than 5 per cent of the issued shares as a scheme

company of its issued shares. The word "securities" is defined in $\mathbf{s} 1$ to include shares, but it is not limited thereto.

26 Section 48(8)(b) Companies Act 71 of 2008. This interpretation assumes that sub-sections (a) and (b) of s 48(8) are to be read disjunctively (as to which, see later).

27 In terms of $\mathrm{s} 117(1)$ (c)(iii) Companies Act 71 of 2008.

28 Section 121 Companies Act 71 of 2008 requires that any person making an offer which if accepted would result in an affected transaction is obliged to comply with all of the reporting or approval requirements of Part C of Chapter 5 of the Companies Act 71 of 2008 and the Takeover Regulations, (except to the extent that the TRP has granted an exemption), and all persons are prohibited from giving effect to an affected transaction unless the TRP has either issued a compliance certificate or has granted an exemption in respect of the specific transaction. 
of arrangement as contemplated in section 114 means that what is covered by the definition of an affected transaction has been expanded. ${ }^{29}$

A re-acquisition by a company of less than 5 per cent would not automatically trigger the application of sections 114 and 115. Does this mean that any such re-acquisition is not an arrangement as contemplated in section 114 (and, assuming it involves a regulated company, therefore not an affected transaction as defined) unless the company proposing it designates it as part of what it calls a scheme of arrangement? Such a re-acquisition by a regulated company might trigger the obligation to make a mandatory offer under section 123 and a mandatory offer as contemplated in that section is in any event defined as an "affected transaction". ${ }^{30}$ However, if such a reacquisition does not trigger this obligation, the question remains - is it only where the company proposing such a re-acquisition designates it as part of what it calls a scheme of arrangement that it becomes a scheme of arrangement?

29 As the word "acquisition" is defined in s 117(1)(a) of the Companies Act 71 of 2008 to include an acquisition by a regulated company of its own securities as contemplated in $\mathrm{s} 48$, it would seem that a re-acquisition by a regulated company of its own securities could potentially trigger the disclosure obligations of $s$ 122. An acquisition of a beneficial interest in voting securities of a regulated company to the extent contemplated in $s$ 122(1) is included under the definition of an affected transaction by $\mathrm{S} 117(1)(\mathrm{c})(\mathrm{iv})$. $\mathrm{S}$ 122(1)(a) is triggered when a person "acquires a beneficial interest in sufficient securities of a class issued by that company such that, as a result of the acquisition, the person holds a beneficial interest in securities amounting to $5 \%, 10 \%$, $15 \%$, or any further multiples of $5 \%$, of the issued securities of that class". A re-acquisition by the company could potentially shift the relative holdings in the company and result in a holder of securities in the company acquiring a beneficial interest in sufficient securities of the company to trigger the disclosure obligations found in s 122. It seems strange that such a holder of securities would need to report the acquisition to the company when in fact it was the re-acquisition by the company that triggered the obligation.

30 See s 117(1)(c)(vi) rw s 123 Companies Act 71 of 2008. S 123(2)(a) requires an offer to be made to all of the holders of remaining securities to acquire those securities if a regulated company reacquires any of its voting securities in terms of $s 48$ or in terms of a scheme of arrangement, and the result is that before the acquisition a person or concert parties were able to exercise less than the prescribed percentage of all the voting rights attached to securities of that company (35 per cent (s 123(5)) and as a result of the acquisition, that person (and concert parties) taking into account securities already held can now exercise at least the prescribed percentage of voting rights attached to the securities of that company. The possibility that a re-acquisition by the company of less than 5 per cent of the issued securities of the company might impose the obligation on a holder of securities who had no vote on the matter in the first place to make mandatory offers to remaining holders of securities might be one reason why all re-acquisitions by a company should be subject to the approval of a special resolution. However, a consideration of the implications of a mandatory offer as an affected transaction is not part of this article. The possibility of applying for an exemption from the application of any provision in Part B or C Chapter 5 Companies Act 71 of 2008 or from the Takeover Regulations in terms of $s$ 119(6) should not be overlooked. 
It is important that it is made clear by the legislature whether what the company is proposing is a scheme of arrangement or not and also if it is therefore an affected transaction, as this clearly impacts on the procedure that must be followed and approvals that must be obtained by the company.

\section{Appointment of an independent expert}

Before a proposed scheme of arrangement can be put to the vote, the company proposing the arrangement is required to retain the services of an independent expert to prepare a report. ${ }^{31}$ The appointment and report is required whether the proposed scheme of arrangement includes a re-acquisition by the company of its own securities or not.

This independent expert must satisfy the qualifications of competence, experience and independence set out in section 114(2)(a). If the scheme of arrangement involves a regulated company, regulation $90(3)^{32}$ would also be relevant. This requires the independent expert to be able to demonstrate to the TRP that he is independent and would reasonably be perceived to be so and that he is competent to act in the circumstances. ${ }^{33}$ Despite the approval given by the TRP, it may (mero motu or after written representations by holders of securities), at any time require the appointment of a further independent expert. ${ }^{34}$

Although a company that proposes a scheme of arrangement that includes a reacquisition of any of its securities would be required to appoint an independent expert, if a company were to propose a re-acquisition outside the context of a scheme of arrangement, it is not obliged by section 48 to appoint an independent expert to compile a report on the proposed transaction. ${ }^{35}$ However, if the proposed

31 Section 114(2) Companies Act 71 of 2008.

32 Of the Takeover Regulations prescribed in terms of s 120 Companies Act 71 of 2008. See Chapter 5 of the Companies Regulations 2011.

33 Regulation 90(3)(a) Companies Regulations 2011.

34 Regulation 90(3)(b) Companies Regulations 2011.

35 Note however that if the transaction fell with s 117(1)(c)(i), (ii), (v) or (vi) Companies Act 71 of 2008 or the obligation to make comparable offers under $s 125$ was triggered or it was a partial offer subject to reg 88 , the offeree regulated company would need to request a ruling from the TRP as to whether or not an independent expert must be retained. See reg 90(1). 
re-acquisition triggers the application of sections 114 and 115 because it involves more than 5 per cent of the issued shares of any class of shares of the company ${ }^{36}$ such an appointment and report is required by section 114(2). Thus, it is important to know whether what is being proposed is a scheme of arrangement or not.

\section{Report by the independent expert and a fair and reasonable opinion}

The task of the independent expert (where one must be appointed) is to compile a report to the board that must be distributed to all of the holders of securities in the company. ${ }^{37}$ This report is clearly to aid the holders of securities in the company in coming to a decision on whether or not to vote to support the special resolution proposing the scheme of arrangement.

Section 114(3) describes the minimum information that needs to be included in the report. As far as the securities and the holders of the securities affected by the proposed scheme are concerned, the report must identify the type and class of securities that would be affected and include the prescribed information relevant to the value of those securities, as well as describe the material effects on the rights of the holders. ${ }^{38}$ The report must also weigh the disadvantages of the scheme against the compensation that would be received. ${ }^{39}$ In doing this, the expert must explain the perceived benefits to the business and the prospects of the company. ${ }^{40}$ As far as directors are concerned, the material interests of such persons must be stated as well as the effect of the proposed arrangement on these persons and their interests. ${ }^{41}$ Further, a copy of section $115^{42}$ and a copy of section $164^{43}$ must be included in the report.

36 See s 48(8) Companies Act 71 of 2008.

37 Section 114(3) Companies Act 71 of 2008.

38 See s 114(3)(a)-(c) Companies Act 71 of 2008.

39 Section 114(3)(d)(i) Companies Act 71 of 2008.

40 Section 114(3)(d)(ii) Companies Act 71 of 2008.

41 Section 114(3)(e)-(f) Companies Act 71 of 2008.

42 Section 115 Companies Act 71 of 2008 explains inter alia the approval requirements, quorum requirements, the exclusion of various voting rights from the assessment of whether or not these were achieved and the circumstances under which a court application may be made in respect of the arrangement.

43 Including a copy of $\mathrm{s} 164$ Companies Act 71 of 2008 will have the effect of highlighting the right of a holder of securities who voted against the proposal to use his appraisal rights. Provided the shareholder complies with the requirements laid down in the section by inter alia giving written 
If the scheme of arrangement involves a regulated company, the Takeover Regulations would also be relevant. Where an offeree regulated company is the subject of an offer ${ }^{44}$ which if accepted would result in an affected transaction, an independent board ${ }^{45}$ of the company is obliged by regulation $110(1)$ to obtain a fair and reasonable opinion from an independent expert. As such an offer could be made by way of a scheme of arrangement, these regulations would be relevant. ${ }^{46}$

A fair and reasonable opinion is one given to an independent board by an independent expert on "the fairness and reasonableness of the consideration for an offer taking account of value and price". ${ }^{47}$ In order for an independent expert to be able to give this opinion, the expert would clearly be required to conduct a valuation of the offeree regulated company and its securities. Regulation 90(4)-(5) indicates the valuation approaches and methods that can be used and regulation 90(6) sets out what must be included in the opinion. The latter focuses on issues such as including a statement as to the purpose of the opinion, the methods employed and documents consulted for the valuation, a statement of a range of values attributable to the relevant securities, and a clear statement about whether or not the offer is fair and reasonable. ${ }^{48}$

The statutory provisions applying to schemes of arrangement ${ }^{49}$ do not specifically require the independent expert to provide a fair and reasonable opinion. Thus if the scheme of arrangement was simply a fundamental transaction and not an affected

notice of their objection to the scheme and by voting against the resolution, (see s 164(3)-(4)) such a shareholder is entitled to demand that the company buy out his shares for fair value ( $\mathrm{s}$ 164(5)-(8)) and, if he does not accept the value offered by the company, to bring a court application asking it to determine the fair value (s 164(14)).

44 Included in the definition of an "offeree regulated company" is a regulated company that is itself the subject of an offer or the securities of which (either partially or entirely) are the subject of an offer: reg 81(o). See s 117(1)(f) Companies Act 71 of 2008 for the definition of "offer".

45 An independent board is defined by reg $81(\mathrm{j})$ as "those directors of an offeree regulated company whom that company has indicated are independent directors".

46 In the context of a scheme of arrangement which is an affected transaction, the offeror is considered to be a person other than the offeree regulated company concerned who, with the cooperation of the company, proposes to acquire securities of that company in terms of a scheme of arrangement contemplated in s 117(1)(iii): reg 81(p)(iii). Such an offeror may act alone or in concert with others.

47 Regulation 81(h) Companies Regulations 2011.

48 The fair and reasonable opinion of the independent expert and the independent board opinion would form part of the circulars which are required to be distributed in terms of reg 106 . See reg $106(3)$ for who is responsible for the various circulars and regs 106(4)(g) and 106(7)(h).

49 Section 114(3) Companies Act 71 of 2008. 
transaction, ${ }^{50}$ although an independent expert would need to be appointed to compile a report, no fair and reasonable opinion is specifically mandated. Although much of the information required to be included in the report by the independent expert would obviously cover similar ground to that which would be covered by the fair and reasonable opinion, it is only if the application of the Takeover Regulations is triggered $^{51}$ that the independent expert's report must also specifically include a fair and reasonable opinion.

\section{Independent board opinion and the solvency and liquidity requirement}

Where the scheme of arrangement involves a regulated company (and thus is an affected transaction as defined), the Takeover Regulations require the independent board of the offeree regulated company (after taking into account the fair and reasonable opinion supplied by the independent expert), to form its own opinion of the offer and of the consideration being offered. ${ }^{52}$ This opinion must then be communicated to the holders of securities in the offeree company that would be affected by the offer. ${ }^{53}$ Note, however, that where the scheme of arrangement does not involve a regulated company and is therefore not subject to the Takeover Regulations, there is no specific statutory provision requiring the board proposing the scheme to express an opinion on the offer and the consideration being offered.

In forming its own opinion, the board of the regulated company would be required either to value the company's securities itself or rely on work performed by the expert. $^{54}$ The board must compare the value and the price with the consideration being offered in order to have a clear basis for its opinion. ${ }^{55}$

50 Although Part A Chapter 5 of the Companies Act 71 of 2008 is headed "Approval for certain fundamental transactions" and schemes of arrangement are regulated by $s 114$, which is included in Part A, no definition of "fundamental transaction" is provided. A scheme of arrangement becomes an affected transaction when it involves a regulated company.

51 For example, where the company proposing the scheme of arrangement is a regulated company or the TRP has ruled that an independent expert is required. See reg 90(1).

52 Regulation 110(2) Companies Regulations 2011.

53 Regulation 110(2) Companies Regulations 2011.

54 Regulation 110(3) Companies Regulations 2011.

55 Regulation 110(4) Companies Regulations 2011. Note that reg 110 also requires the board inter alia to form a view of a range of fair value of the company's securities, and the regulation also explains what must be done if the offer consideration includes securities of the offeror company or if the independent board is not unanimous in its opinion. 
When considering the independent expert's report, the state of the solvency and liquidity of the company may become apparent to the board. However, neither the statutory provisions regulating the independent expert's report in section 114 nor the Takeover Regulations make specific reference to the issue of the solvency and liquidity of the company. Further, the independent expert is not specifically obliged to consider or express an opinion on whether or not the company will be solvent and liquid immediately after implementing the scheme. It is only where the proposed scheme of arrangement involves a re-acquisition by the company of its own issued securities that the solvency and liquidity of the company would be specifically relevant.

Whether or not the arrangement involves a regulated company, the moment the proposed scheme includes the potential re-acquisition by the company of any of its previously issued securities, the application of section 48 (which regulates the acquisition by a company of its own shares or shares of its holding company) is triggered. ${ }^{56}$ Besides certain other limitations and restrictions, ${ }^{57}$ section 48(2)(a) provides that the board of a company may determine that the company will acquire a number of its own shares, "if the decision to do so satisfies the requirements of section $46 "$.

Section 46 prohibits distributions by a company unless there has been compliance with the section. The definition of "distribution" 58 covers a transfer by a company of any of its money or property to or for the benefit of holders of shares (or holders of any beneficial interest in shares) in the company, including such a transfer as a consideration for the acquisition by the company of any of its shares in terms of section 48. Before a distribution can be made, the board must authorise the distribution by resolution, and it must reasonably appear that the company will satisfy the solvency and liquidity test set out in section 4 immediately after completing the proposed distribution. ${ }^{59}$ The board must also pass a resolution acknowledging that it

56 By s 114(4) Companies Act 71 of 2008.

57 See s 48(3) and (8) Companies Act 71 of 2008.

58 Section 1 Companies Act 71 of 2008.

59 Section 46(1)(a)-(b) Companies Act 71 of 2008. 
has applied the solvency and liquidity test and that it reasonably concluded that the company would satisfy it immediately after completing the proposed distribution. ${ }^{60}$

Thus if the scheme of arrangement includes a re-acquisition by the company of its previously issued shares and the consideration for the re-acquisition is company money or property (for example, money raised by the company as a result of the offeror subscribing for new shares in the company), besides the triggering of the application of section $48,{ }^{61}$ section 46 is also triggered. ${ }^{62}$ This has the effect of bringing the solvency and liquidity requirements to the fore, which will be some protection for creditors as well as shareholders whose shares are not being reacquired by company. Although the independent expert is not specifically required by section 114 or by the Takeover Regulations to consider the solvency and liquidity of the company, the directors of the company would be required to give the issue of solvency and liquidity some serious consideration in these circumstances, or face the consequences. ${ }^{63}$

There is no statutory requirement that the consideration paid when a company reacquires its own securities must come from the company. It could potentially be funded by the offeror or come from some other source. Thus if the scheme of arrangement included a re-acquisition of previously issued shares by the company but the consideration to be paid is not money or property of the company, the company would not be making a distribution (as defined) and the solvency and liquidity test should not be relevant. Further, a scheme of arrangement involving for example an expropriation of securities from holders by the company should not require the satisfaction of the solvency and liquidity test if the holders of those securities expropriated were to be compensated by the offeror and not the company. ${ }^{64}$ What may be more relevant in this context (where such a scheme falls within the definition of an affected transaction) is if the offeror is willing and able to

60 Section 46(1)(c) Companies Act 71 of 2008.

61 By s 114(4) Companies Act 71 of 2008.

62 By s 48(2) Companies Act 71 of 2008.

63 See s 46(6) rw s 77(3)(e)(vi) and s 48(7) rw s 77(3)(e)(vii) as well as s 218(2) for potential liability.

64 However, one question that could arise in the context of such an arrangement is if the arrangement is one as between the company and a class of its shareholders. 
implement such a scheme of arrangement. Section 119(2)(a) requires the TRP to regulate affected transactions inter alia in a way that ensures that no person may enter into such a transaction unless they are "ready, able and willing to implement that transaction". This would include the financial ability to settle the offer consideration. Regulations 111(4) and (5) would be relevant in this context. These regulations in essence require the offeror to provide irrevocable, unconditional guarantees that there are sufficient funds to satisfy the cash part of the offer consideration.

The TRP has no authority to express any view on the commercial advantages or disadvantages of a proposed transaction when it exercises its powers and performs its functions. ${ }^{65}$ Although there are certain Takeover Regulations that might impact on the nature and level of consideration offered for securities under an affected transaction, $^{66}$ a holder of securities who opposes a scheme of arrangement altogether or who objects to the consideration being offered could use the appraisal remedy provided in section 164 to ensure that the court decides on what consideration constitutes fair value.

\section{Special resolution to approve the scheme}

Before any scheme of arrangement proposed by the board of a company may be implemented, there must be compliance with the approval requirements set down in section 115. Generally speaking, all schemes of arrangement, whether they involve a regulated company or not and whether or not they include any re-acquisition by the company of its own securities, require approval by way of a special resolution adopted by persons entitled to exercise voting rights on the matter. ${ }^{67}$

65 Section 201(3) Companies Act 71 of 2008.

66 See s 125(2) Companies Act 71 of 2008 for when the obligation to make comparable offers to acquire the securities of each class of issued securities of that company is triggered by certain schemes of arrangement that involve a re-acquisition by a company of any of its voting securities where the company has more than one class of securities. Reg 87 further regulates comparable offers. See also reg 111(2), which stipulates the minimum consideration that must be offered to holders of the same class of securities in the event that an offeror (or concert parties) has acquired securities of the same class within the six months period prior to the commencement of the offer period.

67 See s 115(1)(a) rw 115(2)(a) Companies Act 71 of 2008. If the scheme involves a regulated company and thus falls under the definition of an affected transaction, the TRP must also have 
However, not all re-acquisitions of shares by a company require shareholder approval. Section 48(2) states that "[s]ubject to subsection (3) and (8), and if the decision to do so satisfies the requirements of section 46" the board of a company "may determine that the company will acquire a number of its own shares". Although the Companies Act 1973 required the articles of the company to authorise a reacquisition and approval of the acquisition by way of special resolution, ${ }^{68}$ and made provision for a general approval and a specific approval, ${ }^{69}$ section 48 of the Companies Act 2008 no longer specifically requires either a special resolution approval nor does it distinguish between general and specific approvals. As Van der Linde $^{70}$ points out, it is not clear from the rest of the section "whether the company has to make an offer or whether a shareholder has to agree to the repurchase". Although this does not mean that there are no protections for shareholders, ${ }^{71}$ it is clear that section 48 does not specifically require shareholders to approve all reacquisitions of shares by the company.

It is only if the re-acquisition by the company falls within the provisions of section 48(8) that approval by special resolution is specifically required. Section 48(8)(a) stipulates that a special resolution is required if the decision by the board to acquire its own shares involves the buying back of shares by the company from a director or prescribed officer of the company or a related person. ${ }^{72} \mathrm{~A}$ special resolution is also required to approve a re-acquisition if the decision by the board to re-acquire its own shares involves the acquisition of more than five per cent of the issued shares of any particular class. This is because section 48(8)(b) provides that such an acquisition triggers the requirements of sections 114 and 115, which include the special resolution approval requirement. ${ }^{73}$

issued a compliance certificate or exempted the transaction: $s$ 115(1)(b) rw s 119(4)(b) and s 119(6).

68 See s 85(1) Companies Act 61 of 1973.

69 Section 85(2) and (3) Companies Act 61 of 1973.

70 Van der Linde 2010 TSAR 302.

71 For valuable comment on and an evaluation of the protection for shareholders in the context of a buy back in terms of the Companies Act 71 of 2008, see Van der Linde 2010 TSAR 302-304.

72 Section 48(8)(a) Companies Act 71 of 2008. For the definition of "director" and "prescribed officer" see $s$ 1, and for the definition of "related persons" see s 1 rw s 2(1).

73 Section 48(8)(b) Companies Act 71 of 2008. Note that the threshold could be achieved by a single transaction or by a series of integrated transactions. For the definition of a "series of integrated transactions" see s 1 rw s 41(4)(b). A series of transactions is integrated if consummation of one transaction is dependent on the other or the transactions are entered into 
It should be noted that sub-sections (a) and (b) of section 48(8) are co-joined by the word "and". This could be interpreted to mean that it is only when the decision by the board to acquire a number of its own shares would result in an acquisition from directors or prescribed officers and that this would amount to an acquisition of more than five per cent of the issued shares of any particular class of the company that the approval of a special resolution and the requirements of sections 114 and 115 are triggered. However, when one considers that the requirement of an approval by way of special resolution is included in the requirements of section 115 in any event, it raises questions about what the legislature actually intended.

The specific requirement of approval by special resolution by shareholders when the re-acquisition involves acquiring shares from directors and prescribed officers and related persons is easily understood when one considers the potential for a conflict of interest, and also that it would seem that generally it is a board decision whether to re-acquire or not. Also it would seem advisable as a protective measure that any re-acquisitions by the company from directors and prescribed officers should be subject to the approval of a special resolution and not just re-acquisitions from such persons that exceed the five per cent threshold. The latter is what a conjunctive reading of sub-sections (a) and (b) of section 48 would entail.

Section 115(1) stipulates that a company may not implement a scheme of arrangement unless inter alia it has been approved by a special resolution. Thus it is important to know whether a proposed transaction is a scheme of arrangement or not. This is because if, for example, a company embarks on a re-acquisition outside the context of a scheme of arrangement, it is only if the re-acquisition involves acquiring shares from any director, prescribed officer or related person, and/or ${ }^{74}$ the re-acquisition exceeds the five per cent threshold, that the requirement of a special resolution to authorise the re-acquisition is specifically triggered.

within a period of 12 months, involve the same parties, and involve the acquisition or disposal of an interest in a particular company or asset, or taken together they lead to a substantial involvement in a business activity that did not previously form part of the company's principal activity.

74 Depending on whether one reads sub-sections (a) and (b) of s 48 Companies Act 71 of 2008 conjunctively or disjunctively. 


\section{Court review of the special resolution approving the scheme}

Unlike the provisions regulating schemes of arrangement in the Companies Act 1973, the Companies Act 2008 no longer requires the sanction of the court to call a meeting of holders of securities to consider the scheme. Nor does it require the court to finally sanction the scheme after the special resolution has been passed to make it binding. However, there are circumstances when the court may become involved in a scheme of arrangement.

In terms of section 115(3)(a) of the Companies Act 2008, if the resolution to approve the scheme was opposed by at least 15 per cent of the voting rights that were exercised on the resolution, any person who voted against the resolution may require the company to apply for court approval. This person must make the application within five business days after the vote and the company must then (within ten business days) apply for court approval and pay the costs or treat the resolution as a nullity. ${ }^{75}$ Another situation where the court would become involved is where a person who voted against the resolution applies (within ten business days) and is granted leave by the court to apply for a review of the transaction by the court. $^{76}$

After an application, the court is permitted to review the resolution, and section 115(7) specifies limited grounds on which the court may set aside the resolution. This could occur where the resolution is manifestly unfair to any class of shareholders or where the vote was tainted by a conflict of interest, inadequate disclosure, failure to comply with the Act or the Memorandum of Incorporation or the rules of the company, or other significant and material procedural irregularity.

In order to limit the possibility of the vote on a resolution being materially tainted by a conflict of interest, section 115(4) specifically excludes voting rights controlled by the acquiring party, related persons, and concert parties from the calculation of the quorum and the approval majority for the resolution. To ascertain whose voting rights

75 Section 115(5) Companies Act 71 of 2008.

76 See s 115(3)(b) rw s 115(6) Companies Act 71 of 2008. 
would be excluded, one would have to consider the definition of an "acquiring party". Such a person is defined in the context of a transaction or proposed transaction as a person "who, as a result of the transaction, would directly or indirectly acquire or establish direct or indirect control or increase control over all or the greater part of a company, or all or the greater part of the assets or undertaking of a company". ${ }^{77} \mathrm{~A}$ few issues arise when one attempts to interpret this definition. First, there is the meaning of "all or the greater part of a company" and "all or the greater part of the assets or undertaking of a company". Secondly, when can it be said that a person acquires or establishes control or increases control for the purposes of the definition?

The phrase "all or the greater part of the assets or undertaking" of a company is defined in the Companies Act 2008. In the context of a company's assets it means "more than $50 \%$ of its gross assets fairly valued, irrespective of its liabilities" and in the context of a company's undertaking it means "more than $50 \%$ of the value of its entire undertaking, fairly valued". ${ }^{78}$ This definition is helpful in the context of deciding whether or not it could be said that a company is disposing of all or a greater part of its assets or undertaking under section 112 of the Companies Act 2008. However, it is unclear if it should be taken to suggest that "the greater part of a company" in the definition of "acquiring party" means more than 50 per cent of the company.

The second issue relates to the question of when it can be said that a person acquires or establishes "control" over all or the greater part a company, or all or the greater part of the assets or undertaking of a company.

Section 2(2) of the Companies Act 2008 stipulates when it would be considered that a person controls a juristic person or its business. If the juristic person is a company, a person can be said to control the company if the juristic person is a subsidiary of the first person as determined by section 3(1)(a) or that first person (together with related or inter-related persons) can exercise the majority of the general voting rights

77 Section 1 Companies Act 71 of 2008. For the definition of "act in concert" see s 117(1)(b), and to understand who are related parties see the definition of "related" in s 1 rw s 2.

78 Section 1 Companies Act 71 of 2008. 
associated with the securities of the company or has the right to appoint or elect directors who control the majority of the voting rights on the board. ${ }^{79}$

However, it is important to note that this definition of "control" is specifically stated in section 2(2) to be "[f]or the purpose of subsection (1)" of section 2. Section 2(1) explains how, for the purposes of the Act, it is determined whether an individual is related to another individual, whether an individual is related to a juristic person, or a juristic person is related to another juristic person. In the context of the latter two relationships, reference is made to the concept of control. So, strictly speaking, it is only for the purposes of deciding whether an individual is related to a juristic person or a juristic person is related to another juristic person that the specific definition of "control" in section 2(2) is relevant. This definition of "control" would therefore be relevant in determining if a person is related to an acquiring party, as their votes are also excluded from the calculations by section 115(4).

However, the question arises if this definition of "control" is relevant in deciding if a person is an acquiring party ${ }^{80}$ in the sense that the person (as a result of a transaction) acquires or increases "control" over all or the greater part of a company or all or the greater part of the assets or undertaking of a company. Can it be said that a person acquires control over a company (and thus becomes an "acquiring party" as defined) if as a result of a transaction he is able to exercise a majority of the voting rights associated with the securities of that company, or he acquires the right to appoint or elect directors who control the majority of the votes on the board? Further, is there any difference then between acquiring control over all of a company or its assets/undertaking and acquiring control over only a greater part of the company or its assets/undertaking?

Matters are further complicated by the fact that regulation $81(\mathrm{e})$ of the Takeover Regulations, which would apply to affected transactions, contains its own definition of "control". Regulation 81(e) defines "control" as meaning "the holding of a

79 Section 2(2)(a) Companies Act 71 of 2008. S 3(1)(a) details when a company is a subsidiary of another juristic person.

80 As defined in s 1 Companies Act 71 of 2008. 
beneficial interest in a regulated company equal to or exceeding the specified percentage of voting rights in that regulated company". ${ }^{81}$

This definition of "control" is also not without its problems. First, as the Takeover Regulations apply only to regulated companies and the definition of "control" contained therein specifically refers to regulated companies, it would not be applicable in the context of a scheme of arrangement that does not involve such a company.

Secondly, it is unclear where the "specified percentage" referred to in the definition of "control" in regulation 81(e) is set out. Section 440A(1) of the Companies Act 1973 included a definition of the concept of a "specified percentage" as the percentage prescribed in the rules of the Code. Section $\mathrm{B}(4)$ of the Code stated the specified percentage as being 35 per cent or more of the voting rights of a company. However, the Companies Act 2008 contains no definition of this concept. There is also no definition provided in the Takeover Regulations. Regulation 81(t) does, however, provide a definition of "prescribed percentage" as meaning "the percentage contemplated in section 123(5) and prescribed in regulation 86(1)". Section 123 regulates mandatory offers and requires such an offer to be made when the prescribed percentage of voting rights referred to in section $123(5)$ is achieved or exceeded. Section 123(5) authorises the Minister (on the advice of the Panel) to prescribe a percentage of not more than 35 per cent of the voting securities of the company. Regulation 86(1) sets that percentage at 35 per cent of the issued voting securities of the company.

The approach of the Takeover Regulations would suggest that a person who as a result of a proposed scheme of arrangement would be able to exercise at least 35 per cent of the voting rights attached to the securities of the company would be considered to have acquired "control" over all or the greater part of that company or

81 The definition of "beneficial interest" in the context of a company's securities can be found in $\mathrm{s} 1$ of the Companies Act 71 of 2008 and it focuses on the right or entitlement of a person to receive or participate in distributions relating to the company's securities, or to exercise (or direct the exercise of) any or all of the rights which attach to the securities (this would clearly include voting rights) or to dispose of or direct the disposition of the securities or the distribution. 
its assets or undertaking. Such a person would thus fall under the definition of an "acquiring party" in section 1. Further, it would suggest that a person who is already able to exercise at least 35 per cent of the voting rights (and thus has "control") but who as a result of the proposed scheme would be able to exercise more of the voting rights attached to the securities would be considered to have increased "control". Such a person would thus become an "acquiring party" within the definition contained in section 1. Besides the potential triggering of an obligation to make a mandatory offer to all holders of remaining securities to acquire their securities, ${ }^{82}$ the voting rights controlled by such persons (and related and concert parties) would then be excluded when calculating the percentage of voting rights needed to be present when determining the quorum requirements or required to be voted in support of the resolution or actually voted in support of the resolution. ${ }^{83}$

However, the approach suggested by the definition of "control" in section 2(2) of the Companies Act 2008 in the context of the definition of related persons would mean that a person who as a result of a proposed scheme of arrangement would be able to exercise a majority of the voting rights associated with the securities of that company or who acquires the right to appoint or elect directors who control the majority of votes on the board would be considered to have acquired or established "control" over all or the greater part of that company, or all its assets or undertaking. Such a person would thus fall under the definition of an "acquiring party" in section 1. As such, the voting rights controlled by such a person (and related and concert parties) would be excluded by section 115(4).

It should be noted that the voting rights controlled by an acquiring party, related persons and concert parties are not excluded from the count of the percentage of the holders of securities who voted against the resolution. This is because section 115(4)(b) excludes only voting rights controlled by acquiring persons in determination of the percentage of voting rights "required to be voted in support of a resolution, or actually voted in support of the resolution". Thus a person who might

82 See s 123(2) rw s 123(4) Companies Act 71 of 2008.

83 Section 115(4) Companies Act 71 of 2008. 
become an acquiring party as a consequence of a proposed scheme of arrangement to which he is opposed is not prevented from voting against the resolution. ${ }^{84}$

It is important to know whose voting rights are excluded from the quorum and approval determination in order to ascertain what impact this might have on whether the scheme would be approved or not, and also to ensure that the vote is not tainted by a conflict of interest which would allow the court to set it aside. The uncertainty about whose votes would be excluded created by the lack of clarity as to the meaning of "the greater part of a company" and the meaning of "control" in the context of the definition of "acquiring party" needs to be resolved.

Another basis on which the court could set aside the resolution approving the scheme is where the vote was tainted by inadequate disclosure. In an attempt to ensure that those who are permitted to vote on a resolution to approve a scheme of arrangement receive sufficient information to allow them to make an informed vote, the Companies Act 2008 provides for the appointment of and a report by an independent expert, which report must be circulated to holders of the company's securities. $^{85}$ Where the scheme of arrangement is an affected transaction, the obligation imposed on the TRP to regulate affected transactions in a manner that ensures that all holders of relevant securities are provided with sufficient information and time to enable them to reach a properly informed decision would also be relevant. ${ }^{86}$ This mandate is achieved by stipulating who is responsible for the offer circular in respect of a scheme of arrangement, ${ }^{87}$ what must be included in the offer circular and the offeree response circular, ${ }^{88}$ highlighting the obligation to ensure that material changes in information are reported to holders of securities, ${ }^{89}$ and requiring all documents to receive the approval of the Panel before they are posted or published. ${ }^{90}$ Further, the fact that both the Companies Act 2008 and the Takeover

84 A proposed scheme of arrangement that includes a re-acquisition of shares by the company that disturbs the relative holdings of the remaining shareholders could cause a person to become an acquiring party by establishing or increasing that person's control.

85 See s 114(2) and (3) Companies Act 71 of 2008 considered above.

86 See s 119(2)(d)(ii) Companies Act 71 of 2008.

87 See reg 106(3) Companies Regulations 2011.

88 See reg 106(4)-(8) rw reg 101(7)(a) \& (b). Companies Regulations 2011.

89 Regulation 106(10) Companies Regulations 2011.

90 See reg 117 Companies Regulations 2011. 
Regulations prohibit the implementation of an affected transaction unless there has been compliance with the reporting and approval requirements and the receipt of a compliance certificate will work towards ensuring that a vote on a resolution is not tainted by inadequate disclosure and that the court does not have grounds to set the resolution aside. ${ }^{91}$

In what circumstances a court would set aside a resolution approving a scheme of arrangement on the basis that it was manifestly unfair to any class of holders of the company's securities remains to be seen. Perhaps the courts might be influenced by some of the earlier cases where consideration was given to the principles guiding a court when deciding whether to sanction a scheme of arrangement or to confirm a reduction of share capital. ${ }^{92}$

\section{$7 \quad$ Summary and conclusion}

Unlike the Companies Act 1973, where the definition of "affected transaction" focused on transactions resulting in a change in or consolidation of control, ${ }^{93}$ the definition of "affected transaction" in the Companies Act 2008 initially focuses on specific types of transactions and then generally on other conduct which may or may not achieve a change in or consolidation of control. Whereas a scheme of arrangement would have been regulated as an affected transaction only if it resulted in any of the types of transactions covered by the definition in the Companies Act 1973, a scheme of arrangement between a regulated company and holders of any class of its securities "as contemplated in section 114" is now specifically defined by section 117(1)(c)(iii) of the Companies Act 2008 as an affected transaction. Schemes of arrangement are regulated by Part A of Chapter 5 of the Companies Act 2008. If they are affected transactions as defined, they are also regulated by Part $B$ and $\mathrm{C}$ of Chapter 5 as well as by the Takeover Regulations. Further, such a scheme cannot be given effect to until there is compliance with all of the reporting and

91 See s 121 rw s 119(4)(b) Companies Act 71 of 2008 and reg 102(13). Note also the possibility of an exemption in respect of that particular transaction: see s 121(b)(ii) rw s 119(6).

92 See Luiz 1997 SA Merc LJ 258-260.

93 With control being defined in relation to the ability to exercise at least 35 per cent of the voting rights at meetings of the company: see s $40 \mathrm{~A}(1)$ Companies Act 61 of $1973 \mathrm{rw} \mathrm{s} \mathrm{B}(5)$ of the Code. 
approval requirements of the Act and the Regulations. ${ }^{94}$ Thus, it is important to know if a proposed transaction actually constitutes a scheme of arrangement, because this will impact on the procedure to be followed and the approvals required.

However, other than to stipulate that the board of a company may propose and implement any arrangement between the company and holders of a class of its securities (subject to certain approval requirements) and to list a number of methods that may be included in such an arrangement, including the possibility of a reacquisition of its previously issued securities, section 114(1) provides no definition of a scheme of arrangement.

Whether or not any proposal by a company to re-acquire some of its shares in terms of section 48 would constitute a scheme of arrangement is unclear. The fact that a proposed arrangement as contemplated in section 114, which may result in the reacquisition by a company of any of its securities, clearly triggers the application of section $48,{ }^{95}$ does not answer the question of when an arrangement is an arrangement "as contemplated in section 114". Further, the fact that a re-acquisition by a company of more than five per cent of the issued shares of any class triggers the application of sections 114 and $115^{96}$ does not clarify whether or not such a proposed re-acquisition is a scheme of arrangement. Nor does it clarify whether, if it involves a regulated company, it is also an affected transaction. Although it might not be important to label such a re-acquisition a scheme of arrangement, ${ }^{97}$ it might be important to know whether or not, if it involves a regulated company, it would be considered to be a scheme of arrangement "as contemplated in section 114". This is because that would mean that it would fall within the definition of an affected transaction under section 117(1)(c)(iii) and compliance with the applicable legislation and the Takeover Regulations would be required. It would also mean that the definition of an affected transaction has been expanded to include a re-acquisition by a regulated company of more than five per cent of the issued shares of any class.

94 Section 121 Companies Act 71 of 2008.

95 See s 114(4) Companies Act 71 of 2008.

96 See s 48(8)(b) Companies Act 71 of 2008.

97 Because it is specifically stated that such a re-acquisition is subject to the requirements of ss 114 and 115. See s 48(8)(b) Companies Act 71 of 2008. 
The obligation to retain an independent expert is also affected by whether what is being proposed is a scheme of arrangement. A proposed scheme of arrangement, whether it includes a re-acquisition of securities by the company or not, as well as a proposed re-acquisition which involves more than five per cent of the issued shares of any class of shares of the company, ${ }^{98}$ triggers the obligation to appoint an independent expert to report on the transaction. ${ }^{99}$ However, a proposed reacquisition in terms of section 48 outside the context of a scheme of arrangement or which involves a re-acquisition that does not exceed the five per cent threshold triggers no such obligation. ${ }^{100}$

As a scheme of arrangement involving an offeree regulated company is an affected transaction as defined, the Takeover Regulations become relevant. ${ }^{101}$ These regulations require the independent board of the company to obtain a fair and reasonable opinion from an independent expert. ${ }^{102}$ However, the statutory provisions regulating schemes of arrangement do not specifically require this. Thus, if the scheme of arrangement was simply a fundamental transaction and not an affected transaction (as defined), no fair and reasonable opinion would be specifically required by section 114. However, much of the information required in the independent expert's report would obviously cover similar ground. Further, an independent board of a regulated company proposing a scheme of arrangement is required by the Takeover Regulations to form its own opinion on the offer and consideration and to communicate this opinion to the holders of securities affected. ${ }^{103}$ If, however, the scheme does not involve a regulated company and is simply a fundamental transaction, there is no statutory requirement imposing this obligation.

Although when considering the independent expert's report the state of the solvency and liquidity of the company may become apparent to the board, neither the

98 See S 114(2) and 48(8) Companies Act 71 of 2008 respectively.

99 See S 114(2) and (3) Companies Act 71 of 2008.

100 It was, however, noted that any re-acquisition could trigger the obligation to make a mandatory offer, which is defined as an affected transaction: see s 117(1)(c)(vi) rw s 123 Companies Act 71 of 2008 .

101 See s 117(1)(c)(iii) rw s 118(3) and s 121.

102 Regulation 110(1) Companies Regulations 2011.

103 Regulation Reg 110(2) Companies Regulations 2011. 
statutory provisions regulating the independent expert's report in section 114 nor the Takeover Regulations specifically refer to the issue of solvency and liquidity. Further, the independent expert is not specifically obliged to consider or express an opinion on this. However, a scheme of arrangement involving the re-acquisition by a company of any of its own securities (whether or not it is a regulated company) triggers the application of section $48 .^{104}$ That in turn potentially triggers the application of section 46. As the section latter prohibits distributions by a company unless inter alia the solvency and liquidity requirements in section 4 are complied with and the definition of a distribution includes the transfer of money or property of the company to or for the benefit of shareholders as a consideration for the acquisition of any of its shares under section 48, the solvency and liquidity requirements become relevant. Although the independent expert is not specifically instructed to consider solvency and liquidity, it would be advisable for him to do so. Directors would, however, be required to consider the solvency and liquidity of the company or face the consequences.

All schemes of arrangement (whether they include a re-acquisition by the company of its own securities or not) require the approval of a special resolution ${ }^{105}$ before they can be implemented. However, section 48 does not specifically require shareholders to approve all re-acquisitions by the company of its previously issued shares. It is only if the re-acquisition falls within the provisions of section 48(8) that approval by special resolution is required. Thus if the company embarks on a re-acquisition outside the context of a scheme of arrangement, it is only if the re-acquisition involves acquiring shares from any director, prescribed officer or related person, and/or ${ }^{106}$ the re-acquisition exceeds the five per cent threshold that the requirement of a special resolution to authorise the re-acquisition is specifically triggered.

If the special resolution approving the scheme of arrangement was materially tainted by a conflict of interest, the possibility exists that a court could set the resolution

104 See s 114(4) Companies Act 17 of 2008.

105 See s 115(1)(a) rw s 115(2)(a) Companies Act 17 of 2008.

106 Depending on whether one reads sub-sections (a) and (b) of section 48 Companies Act 17 of 2008 conjunctively or disjunctively. 
aside. $^{107}$ In an attempt to limit this possibility, the Companies Act 2008 specifically excludes the voting rights of an "acquiring party" from the calculation of the quorum and percentage approval requirements. ${ }^{108}$ An interpretation of the definition of "acquiring party" is hampered by the lack of clarity as to the meaning of "all or the greater part of a company" and the definition of "control". The difference between "control" in the context of the definition of related persons in section 2(2) and "control" as understood in the Takeover Regulations raises questions as to whose votes are excluded. This could potentially have an impact on a decision regarding whether any vote to approve a scheme of arrangement is tainted by a conflict of interest or not.

A number of questions could arise in the context of a scheme of arrangement. These range from the issue of whether or not a proposed transaction constitutes a scheme of arrangement to the issue of whose votes may be excluded when the transaction is put to the holders of securities in the company. The fact that schemes of arrangement as fundamental transactions and as affected transactions (as a way of achieving a takeover of a company) are a common commercial occurrence means that it is vital that the provisions regulating them are clear and understandable. In this era of making legislation accessible and understandable, the legislature might do well to revisit some of the relevant provisions.

107 See s 115(7) Companies Act 17 of 2008.

108 See s 115(4) Companies Act 17 of 2008. 


\section{Bibliography}

Luiz Securities Regulation Code

Luiz S An Evaluation of the South Africa Securities Regulation Code on Takeovers and Mergers (Volume 2) (LLD-thesis Unisa 2003)

Luiz 1997 SA Merc LJ

Luiz S "Some Comments on the Application of the Securities Regulation Code on Takeovers and Mergers" 1997 SA Merc LJ 239-264

Luiz 2004 SA Merc LJ

Luiz $S$ "Some Comments on the Definition of an 'Affected Transaction' in the Companies Act" 2004 SA Merc LJ 1-16

Van Der Linde 2010 TSAR

Van der Linde K "Share Repurchases and the Protection of Shareholders" 2010 TSAR 288-308

\section{Register of cases}

Ex parte NBSA Centre Ltd 19872 SA 783 (T)

Ex parte Satbel (Edms) Bpk: In re Meyer v Satbel (Edms) Bpk 19844 SA 347 (W)

Ex parte Satbel (Pty) Ltd (Meyer intervening) 19873 SA 405 (C)

In re National Bank Ltd [1966] 1 All ER 1006 (ChD)

Sefalana Employee Benefits Organisation v Haslam 20002 SA 415 (SCA)

Namex v Kommissaris van Binnelandse Inkomste 19942 SA 265 (A)

\section{Register of legislation, regulations and codes}

Companies Act 61 of 1973

Companies Act 71 of 2008

Companies Regulations 2011 (GN 351 in GG 34239 of 26 April 2011) 
Securities Regulation Code in Takeovers and Mergers (GNR 29 in GG 12962 of 18 January 1991)

\section{List of abbreviations}

SA Merc LJ South African Mercantile Law Journal

TRP Takeover Regulation Panel

TSAR Tydskrif vir Suid-Afrikaanse Reg 